\title{
Cerebral Blood Flow Autoregulation: Effect of Hypercapnia on Cerebral Tissue Gas Concentrations ${ }^{1}$
}

\author{
James A. Kennealy, M.D., ${ }^{2}$ Alva A. Karl, L.A.T., ${ }^{4}$ \\ and John S. Kirkland, M.D., Ph.D. ${ }^{3}$ \\ ${ }^{2}$ Environmental Medicine Division, 6570th Aerospace Medical Research Laboratory, Wright-Patterson \\ Air Force Base, Ohio 45433, ${ }^{3}$ Department of Surgery, Section of General Surgery, University of \\ Michigan, Ann Arbor, Michigan 48109, and ${ }^{4}$ Systerns, Research Laboratories Inc., \\ Dayton, Ohio 45440
}

Received for publication November 3, 1977

In clinical medicine many conditions are encountered which adversely affect the oxygenation and perfusion of the cerebral cortex. Shock, sepsis, and posttraumatic pulmonary insufficiency or adult respiratory distress syndrome are frequently encountered complications of major surgical illness. Prolonged cerebral hypoxia may result in diffuse cerebral damage while other organ systems remain viable. Cerebral oxygen consumption remains relatively constant in conditions of arterial hypoxemia but cerebral utilization of glucose rises sharply. With hypoxia moderate changes in arterial $p \mathrm{O}_{2}$ do not cause significant changes in cerebral blood flow; but more severe hypoxia results in increased blood flow.

Hypercapnia causes a profound increase in cerebral blood flow and markedly improves task performance of humans exposed to acute ambient hypoxia [3]. The

The United States Government's right to retain a nonexclusive royalty-free license in and to copyright covering this paper is acknowledged.

${ }^{1}$ The research reported in this paper was sponsored by the Aerospace Medical Research Laboratory, Aerospace Medical Division, Air Force Systems Command, Wright-Patterson Air Force Base, Ohio 45433. This paper has been identified by the Aerospace Medical Research Laboratory as AMRL-TR-76-37. The experiments reported herein were conducted according to the "Guide for the Care and Use of Laboratory Animals," Institute of Laboratory Animal Resources, National Research Council. latter phenomenon was demonstrated in eight volunteers exposed to mixtures of $6 \%$ carbon dioxide in nitrogen. In all eight subjects, breathing $6 \%$ oxygen resulted in marked confusion or loss of consciousness; however, when the mixture was changed to $6 \%$ oxygen, $5 \%$ carbon dioxide, and $89 \%$ nitrogen, all eight recovered normal intellectual function. Furthermore, subjects were able to tolerate $2 \%$ oxygen with $5 \%$ $\mathrm{CO}_{2}$ [3].

Hypercapnia does not significantly change cerebral oxygen consumption [7]; but because cerebral blood flow is increased, the arterial-venous oxygen difference is reciprocally decreased. It seems logical, therefore, that hypercapnia increases both jugular venous and cerebral interstitial oxygen tensions and that this phenomenon may be important in the amelioration of the effects of hypoxia, perhaps by maintaining aerobic metabolism.

The purpose of this experiment was to observe cerebral oxygen and carbon dioxide tensions in hypercapnic but fully conscious rhesus monkeys during exposure to normal oxygen tensions $(21 \%)$ and ambient hypoxia. Interstitial oxygen and carbon dioxide tension was monitored by a mass spectrometer using the Teflon diffusion catheter $[1,10]$. A permanent cranial implant which allows use of the catheter in conscious monkeys has been described 
TABLE 1

Cerebral Oxygen and Carbon Dioxide Tensions (mm Hg) during Sequential Exposure to Ambient Gases in Four Rhesus Monkeys

\begin{tabular}{|c|c|c|c|c|c|c|c|c|}
\hline MONKEY & & $\operatorname{Air}^{a}$ & $\begin{array}{c}5 \% \mathrm{CO}_{2} \\
\text { in } \\
\mathrm{Air}\end{array}$ & $\operatorname{Air}^{a}$ & $\begin{array}{c}12 \% \mathrm{O}_{2} \\
\text { Nitrogen }\end{array}$ & $\mathbf{A i r}^{a}$ & $\begin{array}{c}12 \% \mathrm{O}_{2} \\
5 \% \mathrm{CO}_{2} \text { in } \\
\text { Nitrogen }\end{array}$ & $\mathrm{Air}^{a}$ \\
\hline \multirow[t]{2}{*}{1} & $p \mathrm{O}_{2}$ & 13 & 19 & 15 & 4 & 17 & 15 & 19 \\
\hline & $p \mathrm{CO}_{2}$ & 52 & 54 & 50 & 44 & 48 & 50 & 49 \\
\hline \multirow[t]{2}{*}{2} & $p \mathrm{O}_{2}$ & 20 & 27 & 22 & 3 & 19 & 18 & 19 \\
\hline & $p \mathrm{CO}_{2}$ & 43 & 49 & 42 & 43 & 42 & 47 & 44 \\
\hline \multirow[t]{2}{*}{3} & $p \mathrm{O}_{2}$ & 16 & 23 & 20 & 8 & 20 & 16 & 21 \\
\hline & $p \mathrm{CO}_{2}$ & 54 & 58 & 51 & 43 & 50 & 55 & 53 \\
\hline \multirow[t]{2}{*}{4} & $p \mathrm{O}_{2}$ & 17 & 25 & 20 & 5 & 20 & 16 & 20 \\
\hline & $p \mathrm{CO}_{2}$ & 48 & 51 & 47 & 43 & 47 & 49 & 47 \\
\hline MEAN & $p \mathrm{O}_{2}$ & $16.5 \pm 2.9$ & $23.5 \pm 3.4$ & $19.2 \pm 3.0$ & $5.0 \pm 2.2$ & $19.0 \pm 1.4$ & $15.7 \pm 0.5$ & $19.7 \pm 1.0$ \\
\hline$( \pm \mathrm{SD})$ & $p \mathrm{CO}_{2}$ & $49.2 \pm 4.9$ & $53.0 \pm 3.9$ & $47.5 \pm 4.0$ & $43.2 \pm 5.0$ & $46.7 \pm 3.4$ & $50.2 \pm 3.4$ & $48.2 \pm 3.8$ \\
\hline
\end{tabular}

${ }^{a}$ Air refers to rest period in compressed air.

[5] and has been used previously in this laboratory to study the response to ambient hypoxia [6].

\section{MATERIALS AND METHODS}

Six rhesus monkeys, Macaca mulatta, were surgically prepared with a chronic stainless steel implant in the parietal area of the skull as described elsewhere [5]. This implant rests extradurally and has a 2 $\mathrm{mm}$ opening to allow insertion of the Teflon catheter through the dura and into the cerebrum. The catheter is held firmly in place by means of an " $O$ " ring in the implant.

Each monkey was anesthetized on the day of the experimental procedure with ketamine hydrochloride (Vetalar) $25 \mathrm{mg} / \mathrm{kg}$ intramuscularly. A Teflon coated catheter of a medical mass spectrometer was inserted through the surgical implant into the cerebrum to a depth of $3 \mathrm{~cm}$ after the dura was penetrated with an 18-gauge needle. The mass spectrometer was the Medspect MS8 manufactured by Scientific Research Instruments, Baltimore, Maryland. The Teflon catheters were previously calibrated in an agitated saline bath at $37^{\circ} \mathrm{C}$. All readings were corrected for water vapor pressure at $37^{\circ} \mathrm{C}$.

The monkey was then placed in a comfortable restraint chair and allowed a minimum of $3 \mathrm{hr}$ for recovery of full consciousness. The restraint chair was equipped with a sealed Plexiglas helmet into which controlled ambient gases were introduced at a constant flow of 20-22 liter per min. Each monkey was exposed sequentially to $5 \%$ carbon dioxide in air, $12 \%$ oxygen in nitrogen, and $12 \%$ oxygen with $5 \%$ carbon dioxide in nitrogen. Each exposure was for about $15 \mathrm{~min}$ followed by a $15 \mathrm{~min}$ rest period on compressed air. This was sufficient to allow cerebral gas tensions to stabilize.

\section{RESULTS}

Table 1 lists the steady-state intracerebral gas tensions in four monkeys and includes mean values for each experimental condition. The control values obtained with compressed air are $p \mathrm{O}_{2} 16.5 \mathrm{~mm} \mathrm{Hg}$ and $p \mathrm{CO}_{2} 49.2 \mathrm{~mm} \mathrm{Hg}$. Previous work in this laboratory, including 11 procedures on five animals, demonstrated control values of $p \mathrm{O}_{2}$ $13.5 \pm 3.5 \mathrm{~mm} \mathrm{Hg}$ and $p \mathrm{CO}_{2} 50.4 \pm 7.9$ $\mathrm{mm} \mathrm{Hg}$. 
The simple addition of $5 \%$ carbon dioxide to compressed air resulted in an increase in cerebral $\mathrm{pO}_{2}$ to $23.5 \mathrm{~mm} \mathrm{Hg}$ and increase in $p \mathrm{CO}_{2}$ to $53.0 \mathrm{~mm} \mathrm{Hg}$. With removal of the $\mathrm{CO}_{2}$, there is a residual effect upon cerebral $p \mathrm{O}_{2}$ which decreased only to 19.2 $\mathrm{mm} \mathrm{Hg}$.

The $12 \%$ oxygen in nitrogen resulted in a profound effect upon cerebral $\mathrm{pO}_{2}$ which dropped to $5.0 \mathrm{~mm} \mathrm{Hg}$. Both this value and the decreased $p \mathrm{CO}_{2}$ are again consistent with previous results [6]. The addition of $5 \%$ carbon dioxide to the $12 \%$ oxygen mixture results in a remarkable amelioration of the effect upon cerebral $p \mathrm{O}_{2}$. Instead of decreasing to $5.0 \mathrm{~mm} \mathrm{Hg}$, the $p \mathrm{O}_{2}$ remains at $15.7 \mathrm{~mm} \mathrm{Hg}$, very close to the original control value on air. The cerebral carbon dioxide value of $50.2 \mathrm{~mm} \mathrm{Hg}$ is also close to control.

In two other monkeys arterial and venous blood gas determinations were obtained during both hypoxic stress and hypoxia with hypercarbia. These data show the development of arterial hypocarbia in the hypoxic state, while $5 \% \mathrm{CO}_{2}$ resulted in a maintenance of normal arterial $p \mathrm{CO}_{2}$. While relative hypoxia was present in both experimental circumstances, the $p \mathrm{O}_{2}$ was higher in animals breathing supplemental $\mathrm{CO}_{2}$.

\section{DISCUSSION}

The cerebrovascular response to hypercapnia, hypocapnia, and hypoxia has been extensively investigated, but questions concerning mechanism of response persist [9]. Cerebrovascular resistance is exquisitely sensitive to changes in arterial $p \mathrm{CO}_{2}$, and mathematical models using arterial $p \mathrm{CO}_{2}$ to predict cerebral blood flow have been developed in the rhesus monkey as well as other species. An eightfold change in cerebral blood flow occurs as arterial $p \mathrm{CO}_{2}$ increases from 15 to $150 \mathrm{~mm} \mathrm{Hg}$ in anesthetized monkeys [11].

In previously reported data [6] in five animals exposed to varying concentrations of oxygen in nitrogen, the cerebral $\mathrm{pO}_{2}$ and $p \mathrm{CO}_{2}$ averaged $13.5 \pm 3.5 \mathrm{~mm} \mathrm{Hg}$ $\left(p \mathrm{O}_{2}\right)$ and $50.4 \pm 7.9 \mathrm{~mm} \mathrm{Hg}\left(p \mathrm{CO}_{2}\right)$ while breathing compressed air. With exposure to decreasing ambient oxygen the cerebral $\mathrm{pO}_{2}$ decreased to a $p \mathrm{O}_{2}$ of $2.5 \pm 2.7 \mathrm{~mm} \mathrm{Hg}$ at an ambient oxygen concentration of $10.7 \%$. Cerebral $p \mathrm{O}_{2}$ is almost linearly related to arterial and ambient $p \mathrm{O}_{2}$. Cerebral $p \mathrm{CO}_{2}$ progressively fell with increasing hypoxia secondary to hyperventilation in the spontaneously breathing animal.

Moderate changes in arterial $p \mathrm{O}_{2}$ do not cause significant changes in cerebral blood flow; but more severe hypoxia, with arterial $\mathrm{pO}_{2}$ less than about $50 \mathrm{~mm} \mathrm{Hg}$, results in increased blood flow $[4,8,13]$. Since this is the level at which progressive cerebral tissue lactic acidosis is reported to occur, the controlling factor is probably not the tissue $\mathrm{O}_{2}$ but tissue $\mathrm{pH}$ [4].

Thus, both arterial $p \mathrm{CO}_{2}$ and, at low levels, $p \mathrm{O}_{z}$ are important factors in determination of cerebral blood flow and these two seem to be additive [12].

In our study, arterial $p \mathrm{CO}_{2}$ was not controlled in the simple hypoxic state and fell duc to hyperventilation. With simple hypoxia and no supplemental carbon dioxide, the cerebral $p \mathrm{CO}_{2}$ fell from $47.5 \mathrm{~mm}$ $\mathrm{Hg}$ to $43.2 \mathrm{~mm} \mathrm{Hg}$. Breathing a mixture of $5 \%$ carbon dioxide and $12 \%$ oxygen in nitrogen resulted in a cerebral $p \mathrm{CO}_{2}$ of 50.2 $\mathrm{mm} \mathrm{Hg}$.

The reported restoration of task performance and electrical activity in hypoxemia by carbon dioxide administration is probably due to the maintenance of a relatively normal cerebral tissue $p_{2} \mathrm{O}_{2}$ [3]. During hypoxia, cerebral oxygen consumption is relatively constant, but carbohydrate metabolism is altered and production of lactic acid by the brain increases [2]. This indicates an increase in anaerobic metabolism which is a much less efficient means of oxidative phosphorylation, and this, in turn, may be responsible for cerebral dysfunction.

Restoration of near normal cerebral $\mathrm{pO}_{2}$ by carbon dioxide inhalation is demonstrated in this study; and this phenomenon, as a means of preserving aerobic me- 
tabolism and normal $\mathrm{pH}$, may well account for the protective effect of carbon dioxide.

It seems likely that the preservation of near normal tissue oxygen tension is mediated by the increased cerebral blood flow and improved arterial $p \mathrm{O}_{2}$ due primarily to hypercapnia. Increased blood flow allows for a decreased arterial-venous oxygen difference and presumably then, a decreased arterial-tissue oxygen difference as demonstrated in this experiment.

\section{SUMMARY}

Cerebral tissue oxygen and carbon dioxide tensions were monitored continuously in six rhesus monkeys using a Teflon coated catheter and a medical mass spectrometer. The monkeys were exposed to several ambient gas mixtures in a sealed helmet. Gases included air, $12 \%$ oxygen in nitrogen, and $12 \%$ oxygen with $5 \%$ carbon dioxide in nitrogen. Twelve percent oxygen in nitrogen resulted in a marked decrease in tissue $p \mathrm{O}_{2}$ to $5.0 \pm 2.2 \mathrm{~mm} \mathrm{Hg}$ from a control of $16.5 \pm 2.9$. The addition of $5 \%$ carbon dioxide to the $12 \%$ oxygen provided almost complete amelioration of the decline in tissue $\mathrm{pO}_{2}$ with a mean value of 15.7 $\pm 0.5 \mathrm{~mm} \mathrm{Hg}$.

\section{CONCLUSIONS}

These results are demonstrated in diffusely ischemic cerebral tissue secondary to arterial hypoxemia. Such states may occur with shock, hypotension, and pulmonary insufficiency. Focal cerebral ischemia due to cerebrovascular insufficiency is frequently not improved or actually exacerbated by increased arterial $p \mathrm{CO}_{2}$. Further study is indicated to define clinical conditions in which supplemental $\mathrm{CO}_{2}$ might improve cerebral oxygenation.

\section{ACKNOWLEDGMENT}

The authors wish to thank Ms. Virginia Cornick for her excellent technical assistance.

\section{REFERENCES}

1. Brantigan, J. W., Gott, V. L., and Martz, M. N. A Tefion membrane for measurement of blood and intramyocardial gas tensions by mass spectroscopy. J. Appl. Physiol. 32: 276-282, 1972.

2. Cohen, P. J., Alexander, S. C., Smith, T. C., Reivich, M., and Wollman, H. Effects of hypoxia and normocarbia on cerebral blood flow and metabolism in conscious man. J. Appl. Physiol. 23: $183-189,1967$.

3. Gibbs, F. A., Gibbs, E. L., and Lennox, W. G. The value of carbon dioxide in counteracting the effects of low oxygen. Aviat. Med. 14: 250-261, 1943.

4. James, I. M., Millar, R. A., and Purves, M. J. Observations on the extrinsic neural control of cerebral blood flow in the baboon. Circ. Res. 25: $77-93,1969$.

5. Kennealy, J. A., Brown, R. D., Karl, A. A., Hogue, F. W., and Beuhring, W. J. A chronic implant for intracerebral mass spectrometric gasometry in the rhesus monkey. Lab. Animal Sci 26: $230-233,1976$.

6. Kennealy, J. A., Witte, F. P., Brown, R. D., Kirkland, J. S., and Karl, A. A. Intracerebral oxygen and carbon dioxide tensions in the rhesus monkey. Aviat., Space Environ. Med. 47(10): 1052-1055, 1976.

7. Kety, S. S., and Schmidt, C. F. The effects of altered arterial tensions or carbon dioxide and oxygen on cerebral blood flow and cerebral oxygen consumption of normal young men.J. Clin. Invest. 27: 484-492, 1948.

8. Kogure, K., Scheinberg, P., Reinmuth, O. M., Fujishima, M., and Busto, R. Mechanisms of cerebral vasodilatation in hypoxia. J. Appl. Physiol. 29: 223-229, 1970.

9. Lassen, N. A. Control of cerebral circulation in health and disease. Circ. Res. 34: 749-760, 1974.

10. Owens, G., Belmusto, L., and Woldring, S. Experimental intracerebral $\mathrm{pO}_{2}$ and $\mathrm{pCO}_{2}$ monitoring by mass spectrography. J. Neurosurg. 30: 110-115, 1969.

11. Reivish, M., Arterial $\mathrm{pCO}_{2}$ and cerebral hemodynamics. Amer. J. Physiol. 206: 25-35, 1964.

12. Shapiro, W., Wasserman, A. J., and Patterson, J. L. Human cerebrovascular response to combined hypoxia and hypercapnia. Circ. Res. 19: 903-910, 1966.

13. Shimojyo, S., Scheinberg, P., Kogure, K., and Reinmuth, O. M. The effects of graded hypoxia upon transient cerebral blood flow and oxygen consumption. Neurology 18: 127-133, 1968.

14. Siesjo, B. K., and Nilsson, L. The influence of arterial hypoxemia upon labile phosphates and upon extracellular and intracellular lactate and pyruvate concentrations in the rat brain. Scand. J. Clin. Lab. Invest. 27: 83-96. 1971. 